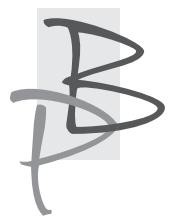

\title{
Patterns of Memory in Askold Melnyczuk's Novels as an Example of Ukrainian-American Émigré Fiction
}

\begin{abstract}
Although Ukrainian emigration to North America is not a new phenomenon, the dilemmas of memory and amnesia remain crucial in Ukrainian-American émigré fiction. The paper focuses on selected novels by Askold Melnyczuk (What is Told and Ambassador of the Dead) and analyzes how traumatic memories and family stories of the past shape the American lives of Ukrainian emigrants. The discussion of the selected Ukrainian-American émigré novels focuses on the dilemmas of remembering and forgetting in the construction of both Ukrainian and American narratives of the past. The voluntary amnesia of the American-born Ukrainians in Melnyczuk's novels confronts their parents' dependence on the past and their inability to abandon it emotionally. Memories of 'the old country' make them, similarly to Ada Kruk, ambassadors of the dead. The expression becomes a metaphoric defini-
\end{abstract}

\footnotetext{
Marta Koval is an Associate Professor at the Institute of English and American Studies, University of Gdansk. Her academic interests include postwar American fiction, memory studies, historical novel transformations in the late $20^{\text {th }}$ - early $21^{\text {st }}$ centuries, exile fiction, and American ethnic fiction. She is the author of two books - Play in the Novel, Playing the Novel: On John Barth's Fiction (2000) and "We Search the Past... for Our Own Lost Selves. Representations of Historical Experience in Recent American Fiction" (2013), and has published numerous essays on post-WWII American fiction and exile fiction. She visited Michigan State University as a Senior Fulbright scholar in 2004-2005.
} 
tion of those wrapped by their repressed, fragmentary and sometimes inaccessible memories. Crucial events of European history of the $20^{\text {th }}$ century are inscribed and personalized in the older generation's stories which their children are reluctant to hear. For them, their parents' memories became a burden and a shame. Using the concept of transgenerational memory, the paper explores the challenges of postmemory, and eventually its failure.

Key words: émigré fiction, immigration, memory, amnesia, nostalgia, identity.

Ukrainian-American literature shares many features characteristic of other ethnic literatures in the USA. Even a brief and superficial review of contemporary ethnic American fiction (Jeffrey Eugenides, Aleksandar Hemon, Dominica Radulescu, Téa Obreht, Irene Zabytko, Amy Tan to mention just a few writers' names) shows an ubiquitous centrality of the motif of remembering and amnesia that each ethnic literature develops in a culturally specific way determined by history of the community it respresents. Characters' memory in Ukrainian-American émigré fiction is deeply rooted in the traumatic reminiscences of "the old country" they preserved and cherished in the USA and passed on to younger generations. From that perspective, Askold Melnyczuk's novels What is Told (1994) ${ }^{1}$ and Ambassador of the Dead $(2001)^{2}$ can be identified as fictions of generational memory (Astrid Er11 's term $)^{3}$. It is a specific type of writing that addresses the "complex constellations of generationality and genealogy," i.e. intersections of generationality and genealogy, and mnemonic transmission within these constellations ${ }^{4}$

1 A. Melnyczuk, What is Told, Byfield: PFP, Inc, MA 2011.

2 Idem, Ambassador of the Dead, Washington D.C.: Counterpoint Press, 2001.

3 A. Erll explores the concept of generational memory in her contribution to Memory Unbound: Tracing the Dynamics of Memory Studies (Berghahn Books, 2017).

4 Idem, Fictions of Generational Memory: Caryl Phillips's In the Falling Snow and Black British Writing in Times of Mnemonic Transition, [in] Memory Unbound: Tracing the Dynamics of Memory, Ed. L. Bond, S. Craps, and P. Vermeulen, New York 2017, p. 111. 
and shows how the controversial relations of the characters with their past function in the construction of their new (American) identity. Erll develops and translates into modern cultural, social, and political terms the concept of generation that was proposed by Karl Mannheim in his 1928 essay "The Problem of Generations"5. Following Mannheim, she writes about generation as a twofold term that can be understood as generationality, i.e. generational identity and also as genealogy ${ }^{6}$. In other words, the scholar identifies diachronic (vertical) and synchronic (horizontal) generations that constitute inter- and intragenerational relations ${ }^{7}$. Erll also broadens the idea of generational memory by introducing the concept of transgenerational memory, which she see as one of the dimensions of memory unbound.

Until recently, the principle of transgenerational memory has been expressed clearly only in Marianne Hirsch's influential concept of postmemory ${ }^{8}$. However, as Erll notes, traumatic memories constitute only part of the memories that travel between generations ${ }^{9}$, while traumatic memories transmitted between generations are related not only to memories of the Holocaust but also those of wars, genocides, immigration and migration, and exile. The concept of transgenerational memory that brings into play Hirsch's idea of postmemory expands the postmemorial community beyond family boundaries. The latter is achieved by the "conventionality of the familial tropes prevalent in postmemorial writing and art, which provides a space for identification that can, in theory at least, be occupied by any reader or viewer"10. Thus, Hirsch's postmemory becomes a structure of mediation between horizontal and vertical generations

5 Mannheim emphasizes that generations are not exclusively biological entities. They represent social phenomena that share "social location" i.e. experience, temporal framework, and collective memory (Essays on the Sociology of Knowledge (Routledge and Kegan Paul, 1952).

6 A. Erll, Generation in Literary History: Three Constellations of Generationality, Genealogy, and Memory, [in] New Literary History, vol. 45, 2014, p. 385.

7 Idem, Fictions of Generational Memory: Caryl Phillips's In the Falling Snow and Black British Writing in Times of Mnemonic Transition, p. 111.

8 M. Hirsch, The Generation of Postmemory. Writing and Visual Culture After the Holocaust, New York: Columbia University Press, 2012.

9 A. Erll, Fictions of Generational Memory: Caryl Phillips's In the Falling Snow and Black British Writing in Times of Mnemonic Transition, [in] Memory Unbound: Tracing the Dynamics of Memory, op. cit., p. 111.

10 L. Bond, S. Craps, and P. Vermeulen, Introduction. Memory on the Move, [in] ibid., p. 11. 
and is "therefore potentially producible by and available to members of very different generational locations"11.

Melnyczuk's family history was an inspiration for his novels. He is the son of Ukrainian immigrants who used to live in Przemyśl/Peremyshl, near the contemporary eastern border of Poland. His parents left for the USA in 1944, and as a child Askold could closely observe the life of the Ukrainian émigré community. His novels are not autobiographical but the Ukrainian heritage of his family and the neighborhood he grew up in contained many untold stories and experiences America knew nothing or almost nothing about. In the interview Melnyczuk gave in Kyiv in May 2017, he compared the United States to a huge island surrounded by a wall. Modern technologies help to see through it but sometimes you need a ladder to be able to climb the wall and see the world beyond it. The writer admits that the Ukrainian experience of his family was burdensome, at times incomprehensible, but also exciting. In his adult life it became a microscope, then a window, and, finally, binoculars through which he could look at the world ("Rozkazhy meni pro mene").

Although both novels are united by the Ukrainian theme, they offer the reader different insights into the past. Memory models are contingent upon the characters' attitude towards "the old country" and their willingness (or unwillingness) to embrace their new American identity. Prior to their emigration to the US, Melnyczuk's characters nolens volens engaged in the whirlpool of the most tragic events in Eastern Europe in the $20^{\text {th }}$ century. For them, emigration meant peace, a new identity, and very complex relations with the past nobody particularly cared about in the new country. The memorial practices of Melnyczuk's characters are typical of other immigrant groups and ethnic literatures: we deal with another new voice that at a certain point became part of the American literary landscape. As opposed to immigrants from Asia or even the Mediterranean region, Ukrainians seemed to resemble WASPs in their appearance. They spoke a strange language and had obscure religious practices but otherwise they were not much different. Nonetheless, their story of the past was painful, contradictory and incomprehensible. Their country was erased from the map, and they had a problem expressing themselves and telling their stories.

11 A. Erll, Generation in Literary History: Three Constellations of Generationality, Genealogy, and Memory, p. 400. 
While Melnyczuk's novels to be analyzed further in the article are united by the same theme, they differ in their approach to it. Memorial models created in these novels are contingent upon the characters' attitude towards 'the old country' and their willingness (or unwillingness) to embrace their new American identity. Therefore, the reader can trace the evolution of Ukrainian émigré experience and its impact on émigré memorial practice. While in What is Told memories of 'the old country' and references to its folklore, traditions, and language are among the key elements of the narration, Ambassador of the Dead problematizes ethnic elements and brings into the foreground the theme of assimilation, voluntary amnesia, and rejection of Ukrainian identity for the sake of new American identity.

The conflict between the old and new generations in Melnyczuk's fiction is rooted in their vision of the past and determined by the system of values they no longer share. Generational criteria become crucial for the selection and communication of memory. According to Aleida Assmann, the relations between generational memory as a format of social memory and "lived experience" create a complex existential amalgam that helps us to analyze the nature of social communication ${ }^{12}$. The latter is particularly significant in émigré fiction as it brings into play a wide range of social and historical dilemmas.

In Ambassador of the Dead, Adriana (Ada) Kruk's story creates a memoryscape that her younger son Alex and even many of her friends from the past do not seem to understand. Ada clings to the past and wants it to be as attractive and interesting for everyone as it is for her. Her family arrived in the USA from a DP camp a few years after WWII. The war split her life into two parts, not only chronologically but also emotionally and socially: a naïve, happy and nonchalant girl from a well-established family transformed into a sexually attractive young woman who had to face the challenges of a new life, a new community, and a new language. Ada never integrated fully into the new reality, but it did not seem to bother her too much. She never learned to speak good English and she was obsessed with memories of her past. Ada did not really care about her roots, and her past did not seem to give her a sense of national pride. Instead, stories of the past were a link to a world that she associated 
with stability and confidence, and that helped her to identify herself in the new world.

Ada was unwilling or even unable to abandon her past, although she appreciated the comfort and predictability of her American life and "thanked God for a haven in which to recover from Europe where neighbors sharpened knives against each other, revenge their sustaining force"13. The woman suffered OWS - Old World Syndrome - which was the code her son and his friends used to describe the adult behaviors they were not able to explain otherwise, "words like trauma, manic depression being unfamiliar" to them ${ }^{14}$.

Ada's connection with the past was the connection with the dead - dead aunts, uncles, cousins, neighbors, and friends. For her, they were like moths fluttering around:

Ada carried two decades of memories from another country, full of other buildings and other people, all of which had been real as the ones surrounding her now; they superimposed themselves onto the faces she saw in the streets, so she had to stop herself from waving to a man she thought she recognized, a former classmate, a second cousin who once lived around the corner on whom she'd had a crush and who quite possible still lived there, in a city on the other side of the world where life continued without her, and where even at this moment someone she'd known in short pants may well have been thinking of her ${ }^{15}$.

Ada's "embassy of the dead" which she established during her stay in the DP camp was her link with the past, where she looked for support and understanding. In her dreams and visions the past was alive and people from the past, even those who were dead, participated in her present life, counseled and supported her in difficult moments of her life. Ada saw her past life as a story, and it added fictitiousness to her experience.

Ada's attachment to the past annoyed her children. Their parents' country disappeared from the map because of the change of borders in Eastern Europe

13 A. Melnyczuk, Ambassador of the Dead, p. 72.

14 Ibid., p. 97.

15 Ibid., p. 78. 
after WWII, and that made their identity and origins problematic. For a teenager, like Alex, it created many awkward situations:

Shifting from foot to foot, he stared at the map, which seemed nothing like the one he'd studied at home. It wasn't there. Try as he might, he couldn't find the old country anywhere. Anxiety overwhelmed him: what would he say? What would he tell the teacher? She'd call him a liar, and would she be wrong? He wanted to erase himself the way Mrs. Linnaean swiped clean the board ...

"Not there," she said confidently. "That's Russia now." 16

Ada failed to transmit her stories to either of her sons, and we can view Melnyczuk's novel as the fiction of failed transgenerational memory. Alex, as well as his older brother Paul, refused to speak Ukrainian even to their mother, and preferred to change his last name at school to Kruko, claiming Italian origin. At least that identity was less problematic than Ukrainian. For Alex, the past was like a monster. Every time Ada tried to tell him a story about her past life "Alex seethed - here was the old world he was learning to hate slipping into the room again. He felt the tribe of hungry ghosts surrounding him with long chalk bodies" 17 . Thus, the past was tiring, annoying and even scary, and Alex saw no point in bringing it up again. "The whole damn Ukrainian mess. They fucked everybody, everybody fucked them, and now their stories fuck us"18. This vulgar description of transgenerational memory shows that postmemory may also acquire an emotionally negative format, when remembering is a curse and amnesia is a blessing: "Self-hatred in his eyes. I knew what he meant - the Ukrainian story was so tangled, it was hard to separate truth from myth, or to decide whose version to believe. Easier to forget it entirely"19. Alex did not feel he needed roots or stories of the past to establish his identity. He was reluctant to adopt the traumatic experience of his mother and to inscribe it into his own life story ${ }^{20}$.

16 Ibid., p. 46.

17 Ibid., p. 67.

18 Ibid., p. 211.

19 Ibid.

20 L. Bond, S. Craps, and P. Vermeulen, op. cit., p. 9. 
Even Ada's best childhood friend Slava seemed reluctant to share her attachment to the old country. Nick, Slava's son, who was a life-long witness to the Kruks efforts at adjustment, compares them with his family. His parents were ideal new citizens who chose voluntary amnesia as the major adjustment tool. Nick's father earned a medical degree and the family moved away from the Ukrainian ghetto. They were not ashamed of their past, but they preferred "slamming the door" on it ${ }^{21}$. Assimilation for them meant psychological comfort and social welfare. Amnesia was the best choice when one had to respond efficiently to the challenges of American life. The old homeland became an abstract place that was difficult to accommodate new realities. Thus, the connection between communicative and cultural memory broke down, while transgenerational generational memory transmission was deliberately brought to an end.

Memories about the old country did not fit American life, or at least the Ukrainian community, obsessed with its own historical offenses and grudges, could not find an appropriate language to tell the story about its traumas. As Nick observes,

My first twelve years I lived in a closed community which couldn't have been more different from that of my neighbors. While this estranged me from my peers, it also gave me purpose and definition that were altered by our move to the suburbs. There traditions were supplanted by instructions in a stream of increasingly complex practical skills enabling me to adapt with ease. Assimilation, however, is never straightforward or painless - to a degree, sanity and humanity depend on keeping faith with a self over time. Without access to your childhood, you risk slipping into the land of Ulro, as the poet Blake called that place where individuals meet each other at the level of appearances alone ${ }^{22}$.

Only Anton, Ada's old friend from the old country, understood her fascination with the past, although he did not share her anxieties. On the contrary, Anton disappointed the local Ukrainian community when during his guest lecture he spoke about the necessity to adjust to the new culture and appreciate

21 A. Melnyczuk. Ambassador of the Dead, p. 30.

22 Ibid., p. 216. 
the heritage of the new homeland. His position could not integrate into the collective memory because it did not fit the general model of Ukrainian-American identity dominated by a "peculiarly Slavic mix of hopelessness, the weight of the past drifting down in invisible webs, raining from the sky in soft, sticky lattices that snared and smothered, leaving me feeling action was impossible"23. The idea of shared memory (Max Silverman's concept) that "eschews self-sufficiency and autonomy"23 did not work out in a hermetic community. Anton's awareness of the past as a trap could not have been accepted because of its openness and flexibility, which were seen as culturally dangerous.

The narration in Melnyczuk's earlier novel What is Told is more historically saturated, hence memory performs a different function there. When the Zabobons still lived in the town of Rozdorizha, where the government changed almost every month (the action took place in 1910-1920s), the memorial practice of its residents focused on material and cultural elements of the Ukrainian national past: songs, legends and food. Zenon Zabobon wanted to preserve them as their identity stabilizers. The same elements functioned as "memory stabilizers" 25 when the family moved to the USA ${ }^{26}$.

The memoryscapes Melnyczuk creates in both novels are complex and open to diverse readings. In What is Told the writer used Ukrainian last names and place names, and deliberately did not explain them to the English-speaking reader. As he mentioned in one of his interviews, he did it intentionally as he wanted to make the reader plunge into the mystery of a language he/she didn't speak ("Rozkazhy meni pro mene"). Those names play an important role in the creation of memoryscape in the novel and add insights that otherwise would have been impossible. Although it is hard to expect a reader to be that inquisitive, Melnyczuk certainly succeeded in creating an enigmatic atmosphere. Those who speak Ukrainian know that "zabobon" means superstition, and Rozdorizhia stands for "crossroads". In Ambassador of the Dead place

23 Ibid., p. 245.

24 L. Bond, S. Craps, and P. Vermeulen, op. cit., p. 7.

25 A. Assmann, Cultural Memory and Western Civilization. Functions, Media, Archives, $1^{\text {st }}$ English edition, New York: Cambridge University Press, 2011, p. 239.

26 Assmann describes different types memory stabilizers that translate physical experience into meaning. She believes that language is the most important among these. 
names also play an important role in the construction of memoryscape, although Melnyczuk proposed English equivalents for them ("Adriana was born in the city of Resurrection on the river Memory"27). The English toponym did not make the specific ethnic atmosphere of the novel less expressive as the writer integrated the Ukrainian theme into the American context using other tools. In What is Told Ukrainian words help to understand the mnemonic priorities of the characters of the novel. Rozdorizha happened to be located at the crossroads of history, and that determined the fate of its residents.

Natalka, one of the protagonists of What is Told, is similar to Ada in her obsession with the past. However, she did not share it with her daughter or other family members. When she learned about her husband's death, she promised that

From now on she'd live in retrospect. In a world where Zenon still breathed, where he walked up and down the room lecturing her on nationalism, the woman's movement, the wisdom of Marx, the role of the peasant. A world where they were both young and future-laden. Nothing more from the outside world would ever enter ${ }^{28}$.

Natalka kept her promise: because of her detachment from the outside world she transformed into a secondary and almost inarticulate character.

The Zabobon family not only remembered the old country, but they also continued living in an imagined space. America changed old friends and gave them the right to forget. Very often the people pretended they didn't recognize their old acquaintances. Similarly to Nick Blud's parents they simply preferred to disconnect themselves from their past. While Nick's parents did it seriously and consciously, in What is Told Americanization is presented in an exaggerated and thus ridiculous form: Uncle George, for example, wore the Indian headband from the five and dime store and wondered why Ukrainians still dressed like Europeans because it was time to assimilate.

In the novel, memories help the immigrants to survive. Most of them lost their social status moving to the US, and meeting those who used to know

27 A. Melnyczuk, Ambassador of the Dead, p. 109.

28 Idem, What is Told, p. 55. 
them when they were important people (lawyers, teachers and politicians) and when their world was still coherent and predictable was both a painful and a rewarding experience. That was the case when memory functioned as an indicator of historical awareness: "The manager at Woolworth's was a twenty-four -year-old Polish kid who knew nothing about the history of relations between Ukraine and Poland. America. Sweet amnesia"29. Amnesia was a problematic choice even for the younger generation of Ukrainian immigrants. They tried to remember, but at times remembrance acquired weird, if not absurd forms. Lastivka's husband, who found life in the States very problematic, clung to the old identity and the old country. However, as opposed to Ada's nostalgic stories of the past, his nostalgia acquired a ridiculous expression: for example, many pieces of furniture in their place were painted yellow-blue which are the colors of the Ukrainian national flag, Arkady made his little son do physical exercises in order to be strong and ready to fight with the enemies of the old country and, as the most absurd idea, he introduced a family ritual of singing the Ukrainian national anthem every day after dinner:

He insisted that Lastivka sit at the yellow-blue piano (he had painted it, the colors of the Ukrainian flag)... Following a few introductory chords, Lastivka sang, in a voice passionate as that of the guitarist in Casablanca, belting out the Marseillaise; Sche ne vmerla Ukraina... The national anthem. Arkady, unlike Victor Lazlo, would not join in... At the end he commented, "You were off-key, nightingale," or "Fortissimo, Slava, fortissimo!" And they began again ${ }^{30}$.

The notion of memory in both novels is linked with the concept of identity: you are what you remember. Memories of the old home country, which after WWII was no longer on the map and its people were often labeled as Nazi collaborators, hurt. Peaceful and stable life in the new country meant either sweet amnesia or the awareness of loss and fear because memories could be too scary to articulate. As Stepan Zabobon noted, "I come from a place where the earth has been trying to speak for so long. I'm afraid when it finally does, the first thing it will do is scream... I know I have no place in America. I came

29 Ibid., p. 135.

30 Ibid., p. 103. 
here to die" 31 . On his deathbed, Stepan scrolled his life back and remembered the turbulent years of his youth in France, the wonderful peaceful years full of passion and adventure. Those memories were not soothing but they let Stepan remind his grandson Bo of what might happen "if you are careless enough to lose a country and a continent" 32 . Thus, memory and bitter immigrant experience became crucial existential elements that accounted for characters' attitudes and perspectives.

What is Told and Ambassador of the Dead present patterns of memory that are based on generational and transgenerational relations shaped by the traumatic experience of immigration. In Melnyczuk's earliest novel, characters' memories interiorize their painful family histories but deliberately leave many stories untold as they do not fit a new American frame of reference. In Ambassador of the Dead, characters' conscious choice of remembering or forgetting as well as failed generational transmittance of memory focalize the creation a new hybrid Ukrainian-American identity and problematize the relations of émigré community with its past. For all his irony and skepticism, Melnyczuk sympathizes with his characters' dependence on the past and very problematic relations with the American present. For them, the past was a story that one could reorder, reconfigure and even repair. While Melnyczuk the writer makes only a few references to the historical past and the traumas his characters had to go through, there is a clear awareness in their lives that "history overtook domesticity, and countless private lives and stories never found their natural end" 33 . This awareness is crucial in the creation of both Ukrainian and American narratives of the past as cultural and social constructions to be painfully remembered, sweetly forgotten or bitterly present in the new life. In any case, the future is recognized as "the only road open for approaching the past" 34 while the past is a combination of both told and untold stories that must be deciphered by everyone in his or her own way.

31 Ibid., p. 138.

32 Ibid., p. 169.

33 Idem, Ambassador of the Dead, p. 263.

34 Ibid., p. 261. 


\section{References}

Assmann, A. (2011). Cultural Memory and Western Civilization. Functions, Media, Archives. $1^{\text {st }}$ English edition. NY: Cambridge University Press.

Assmann, A. (2006). Memory, Individual and Collective. In R. E. Goodin, \& Ch. Tilly (Eds.), The Oxford Handbook of Contextual Political Analysis (pp. 210-226). New York.

Bond, L., Craps, S., \& Vermeulen, P. (2017). Introduction. Memory on the Move. In L. Bond, S. Craps, \& P. Vermeulen (Eds.), Memory Unbound: Tracing the Dynamics of Memory (pp. 1-26). NY: Berghahn Books.

Erll, A. (2017). Fictions of Generational Memory: Caryl Phillips's In the Falling Snow and Black British Writing in Times of Mnemonic Transition. In L. Bond, S. Craps, $\&$ P. Vermeulen (Eds.), Memory Unbound: Tracing the Dynamics of Memory (pp. 109-130). NY: Berghahn Books.

Erll, A. (2014). Generation in Literary History: Three Constellations of Generationality, Genealogy, and Memory. New Literary History, 45(3), 385-409.

Hirsch, M. (2012). The Generation of Postmemory. Writing and Visual Culture After the Holocaust. NY: Columbia University Press.

Mannheim, K. (1952). The Problem of Generations. In Essays on the Sociology of Knowledge. London: Routledge and Kegan Paul.

Melnyczuk, A. (2001). Ambassador of the Dead. Washington D.C: Counterpoint Press.

Melnyczuk, A. (2017, May 22). "Rozkazhy meni pro mene." Discussion with Zabuzhko Oksana. https://www.radiosvoboda.org/a/28502455.html

Melnyczuk, A. (2011). What is Told. Reprint. Byfield, MA: PFP, Inc. 